\title{
Production and Dispersal of Conidia of Leucostoma cinctum in Peach and Cherry Orchards Under Irrigation in Eastern Washington
}

Gary G. Grove, Washington State University, Prosser Irrigated Agriculture Research \& Extension Center, 24106 N. Bunn Road, Prosser 99350-8694, and Alan R. Biggs, West Virginia University, Kearneysville Tree Fruit Research and Education Center, P.O. Box 609, Kearneysville 25430

\begin{abstract}
Grove, G. G., and Biggs, A. R. 2006. Production and dispersal of conidia of Leucostoma cinctum in peach and cherry orchards under irrigation in eastern Washington. Plant Dis. 90:587-591.

The objectives of this study were to determine the seasonal production patterns of Leucostoma cinctum conidia in peach and cherry orchards and the effects of irrigation on dispersal of conidia. Conidia were trapped throughout the year and were present in highest numbers during spring and summer on both cherry and peach. The pathogen was dispersed $1.0 \mathrm{~m}$ by water drops that simulated irrigation drops that would impact cankers during over-the-canopy irrigation. Spore production and dispersal also resulted from the use of over-the-canopy and under-tree impact sprinklers. Although the two irrigation methods were not directly compared, the latter mode dispersed propagules of $L$. cinctum over horizontal distances of about $6 \mathrm{~m}$, a distance sufficient to account for the movement of the pathogen between trees within and across orchard rows. It is concluded that disease management could be improved by alteration of horticultural and irrigation practices.
\end{abstract}

Additional keywords: Leucostoma canker, peach canker

Leucostoma canker (or Valsa canker), caused by Leucostoma cinctum (anamorph Leucocytospora cinctum) and Leucostoma persoonii (anamorph Leucocytospora leucostoma), is the primary canker disease of stone fruits in many regions of the world $(4,5)$. Dead wood is the major source of $L$. cinctum and $L$. persoonii ascospores and conidia in the orchard. Conidia are considered to be the primary source of inoculum for new infections because it may take 2 to 3 years for perithecia to develop and dead wood is usually removed annually when trees are pruned. In Washington, L. cinctum is the primary wood pathogen on sweet cherry (Prunus avium L.) and peach (P. persica (L.) Batsch. $(1,9,16)$. Tree mortality in affected orchards can reach 3 to $6 \%$ per year (G. G. Grove, unpublished). Further economic losses result from the loss of bearing wood on surviving trees. Some growers estimate that this loss of bearing wood further reduces yield by up to $5 \%$ (G. G. Grove, unpublished). The

Corresponding author: G. G. Grove

E-mail: grove@wsu.edu

PPNS No. 0406, Department of Plant Pathology, College of Agricultural, Human, and Natural Resource Sciences Research Center, Project No. 0795, Washington State University, Pullman, WA 991646430 USA.

Accepted for publication 6 December 2005.

DOI: 10.1094/PD-90-0587

(C) 2006 The American Phytopathological Society disease is particularly severe in orchards where over-the-canopy or under-tree impact sprinklers are used for irrigation and where intensive summer pruning is standard horticultural practice. The disease is sporadic and far less damaging in orchards where microsprinkler or drip irrigation is used.

Release and dispersal of conidia of $L$. persoonii was found to occur during rain events in all seasons on French prune in California (2). These authors determined that there was no evidence for any nonwater-borne release of conidia. The primary means of dispersal was shown to be wind-blown rain. Also, increasing time and/or temperature between wetting events was correlated with increased numbers of conidia caught in funnel traps. In Colorado, $L$. persoonii conidia were found to be present in water-borne spore traps in all months from February through November (10). Over the course of the 1-year study, production of conidia appeared more responsive to relative humidity during the period February through June, whereas afterward and through November, production of conidia was more closely correlated with temperature. In Germany, L. persoonii on sweet cherry and $L$. cinctum on peach were observed to sporulate during the entire year, with maxima from November to March, and depending upon rainfall, also in June (16). The number of hours that temperatures were between 10 and $15^{\circ} \mathrm{C}$, the duration of leaf wetness, and the length of time that relative humidity was above $90 \%$ all were correlated with numbers of conidia caught.
Commercial stone fruit production in Washington is limited primarily to irrigated areas east of the Cascade Mountains. There are no studies that have considered seasonal sporulation or addressed the role of irrigation in the sporulation and dispersal of conidia of Leucostoma spp. Furthermore, only one previous study has specifically addressed the production and dispersal of conidia of L. cinctum (17). The objectives of this study were to determine the seasonal production of conidia of L. cinctum on peach and cherry, and to assess conidia production and dispersal during irrigation events with under- and over-the-canopy impact sprinklers.

\section{MATERIALS AND METHODS}

Seasonal production of conidia. Spore samplings were made in both cherry and peach orchards. Cherry studies were conducted from January 2001 until December 2002 in a 5.3-ha orchard located $4 \mathrm{~km}$ north of Prosser, WA. The orchard was comprised of 30-year-old 'Bing' trees planted on Mazzard rootstock on a $2.7 \times$ $5.5 \mathrm{~m}$ (tree $\times$ row) spacing. The orchard was irrigated using under-the-canopy impact sprinklers (Model F33S, Nelson Irrigation, Darra, Queensland, Australia). Peach studies were conducted during 1993 to 1995 in a 12.4-ha orchard located $5 \mathrm{~km}$ north of Wapato, WA, and comprised of 12-year-old cv. Redhaven peaches. Trees were planted on a $4.3 \times 4.9 \mathrm{~m}$ spacing and irrigated using over-the-canopy model $30 \mathrm{H}$ impact sprinklers (Rainbird, Inc., Glendora, CA) positioned about $2 \mathrm{~m}$ above tree canopies. Canker incidence was nearly $100 \%$ in both orchards. Twenty cankers on each host were used to study conidia production. To accommodate water-borne spore traps identical to those described previously (8), cankers were chosen that were located within $1.5 \mathrm{~m}$ of the proximal end of main scaffold branches and positioned 1 to $2 \mathrm{~m}$ above the orchard floor. To facilitate the collection of rain- and washwater, triangular funnels were prepared from $0.025-\mathrm{mm}$ aluminum sheeting. A semicircular notch was cut in the broad end of the funnel so that the funnel would fit snugly against the cankered branches. The aluminum was creased longitudinally to form a path for water flow. The notched end of the funnel was placed on the branch bottom immediately beneath the canker and secured with pieces of aluminum wire. 
The opposite end of the funnel was then tilted downward at a 45-degree angle, terminating about $2.5 \mathrm{~cm}$ inside the spore trap opening. Cankers were washed at monthly intervals by applying about $100 \mathrm{ml}$ of sterile distilled water to canker surfaces with a small wash bottle. If rainwater was present in the traps, cankers were washed as described above and the total volume of water in the spore trap determined with a graduated cylinder. Effluent was transferred to 0.95-liter Mason jars and transported to the laboratory. The number of conidia per milliliter of effluent was determined using a hemacytometer. The numbers of conidia per $\mathrm{mm}^{2}$ of canker surface area was determined by dividing the estimated total number per volume of wash water by canker surface area. Cankers were either circular or elliptical in shape, and their surface areas were estimated by substituting the measured canker radii in formulae for determining the surface area of a circle $\left(\pi r^{2}\right)$ or ellipse $\left(\pi r_{1} r_{2}\right)$. A Campbell Scientific CR-10 Datalogger located $0.5 \mathrm{~km}$ from the orchard provided continuous measurements of temperature, precipitation, relative humidity, leaf wetness, wind speed, wind direction, and solar radiation. To verify the presence of $L$. cinc- tum in canker wash samples, effluent from some cankers was placed directly onto Leucostoma selective medium (LSM; G. G. Grove unpublished) containing $12.5 \mathrm{~g}$ of malt extract and $20.0 \mathrm{~g}$ of Difco agar per liter. The base medium was amended with imazilil at $25 \mu \mathrm{g} / \mathrm{ml}$, terrazole at 100 $\mu \mathrm{g} / \mathrm{ml}$, tetracycline at $100 \mu \mathrm{g} / \mathrm{ml}$, streptomycin sulfate at $100 \mu \mathrm{g} / \mathrm{ml}$, and chloramphenicol at $50 \mu \mathrm{g} / \mathrm{ml}$ after autoclaving. Cultures were incubated 10 to 15 days at $20^{\circ} \mathrm{C}$, and putative colonies of $L$. cinctum were confirmed by microscopic observation at $\times 20$. In the peach orchard, the effluent collected in traps was removed immediately prior to each over-the-canopy irrigation set and the concentration of spores of $L$. cinctum determined as described above. Traps were reattached after trees had dried following the irrigation set.

Production of conidia during overthe-canopy irrigation. The water-borne spore traps were also used to study the production and dispersal of conidia during over-the-canopy irrigation events in the peach orchard. Samples were taken during four irrigation events in 1994 and seven events in 1995. Traps were emptied of any natural precipitation prior to irrigation studies and the water processed as de- scribed above. Irrigation water was then applied beginning at 0615 PDT and canker effluent collected in the aforementioned traps for about $6 \mathrm{~h}$. The concentration of conidia of $L$. cinctum was determined as described above.

Dispersal of $L$. cinctum conidia. Laboratory experiments. Active cankers about 6 $\mathrm{cm}$ long were collected from peach branches and used in laboratory experiments. Cankers were secured horizontally to a ring stand. The canker was moistened with $50 \mathrm{ml}$ of sterile distilled water $5 \mathrm{~min}$ before experiments commenced. Petri dishes containing $20 \mathrm{ml}$ LSM were placed at $20-\mathrm{cm}$ intervals to a distance of $100 \mathrm{~cm}$ from the canker. Four respective rows of dishes were positioned at $0,90,180$, and 270 degrees azimuth from the canker. In order to mimic the impaction of droplets from over-the-canopy sprinklers and the dripping of irrigation from foliage and limbs in the tree canopy, $10 \mathrm{ml}$ of sterile distilled water was released from a burette positioned $2 \mathrm{~m}$ above the canker and allowed to impact the canker surface. Two dishes were placed at each position: the cover of one dish was removed during the release of water while the other was left covered at all times. At the conclusion of

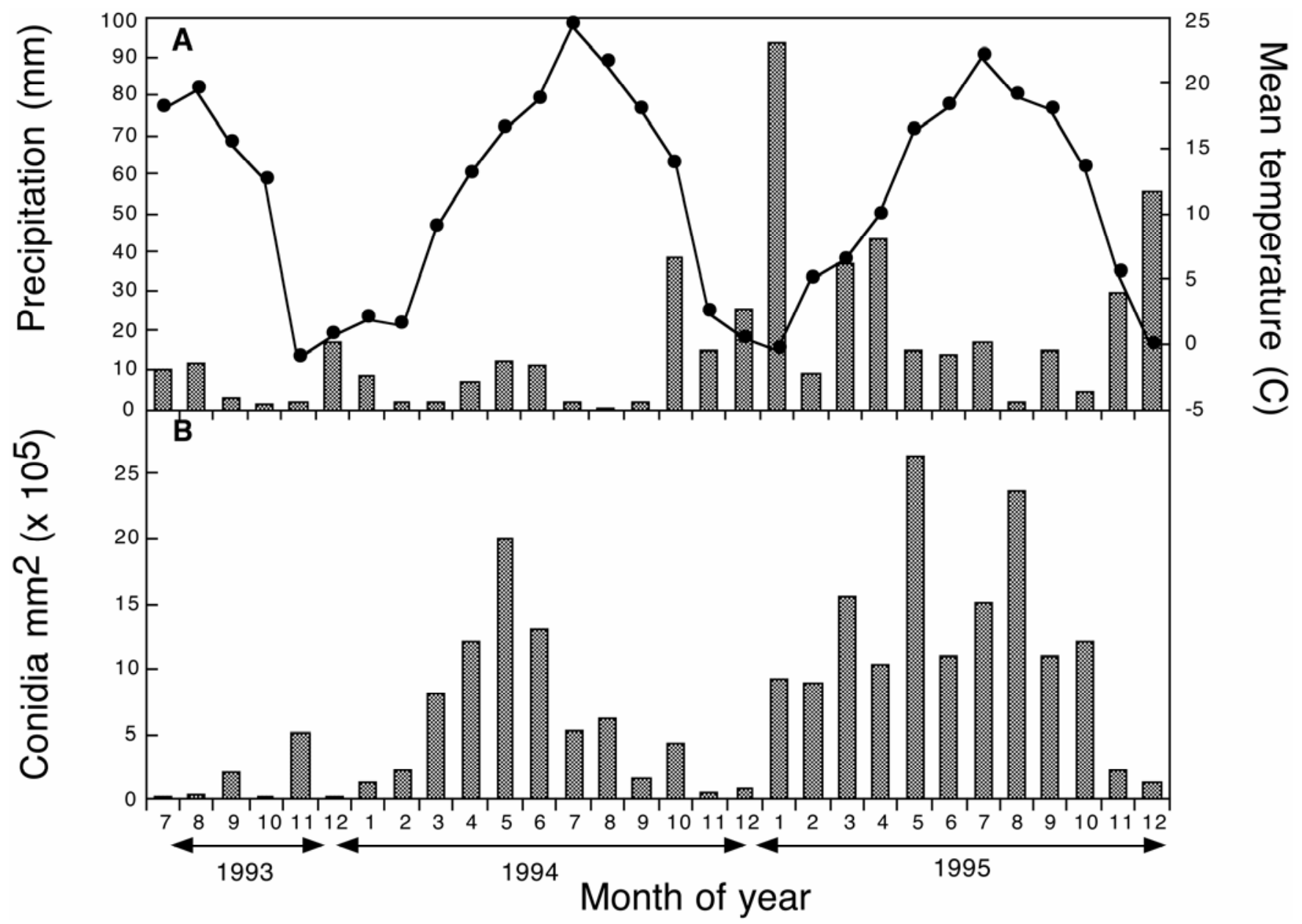

Fig. 1. Effect of time of year on sporulation of Leucostoma cinctum on cankers on 'Redhaven' peach trees in Wapato, WA, during 1993 to 1995 . Presented are A, average monthly temperature and total monthly precipitation and $\mathbf{B}$, number of conidia per $\mathrm{mm}^{2}$ of canker surface area collected from water-borne spore traps. Values represent the mean number of conidia per $\mathrm{mm}^{2}$ recovered from 20 cankers. 
the experiment, cultures were as described above. The number of colonies of $L$. cinctum was determined by microscopic observation at $\times 20$. The experiment was conducted twice.

Orchard studies using over-the-canopy sprinklers. The peach orchard was used for these dispersal studies with water applied in $12-\mathrm{h}$ sets at approximately $2.46 \mathrm{~kg} / \mathrm{cm}^{2}$. The dispersal of $L$. cinctum was studied by placing 100-mm-diameter petri dishes containing LSM medium on steps of 1.8-m aluminum ladders placed about $1 \mathrm{~m}$ from infected trees. Dishes were positioned at heights of 0.5 to $1.8 \mathrm{~m}$. Ladders were positioned so that they would be within the tree drip lines. Totals of 72 and 84 petri dishes were used in the two runs of the experiment (four plates each were also positioned in the crotches of three trees during the second experiment). The covers of onehalf of the plates were removed immediately prior to the beginning of the irrigation set. Sets commenced at 0615 PDT, and the plates were uncovered for $15 \mathrm{~min}$. At the conclusion of the experiment, dishes were covered and transported to the laboratory and incubated as described above. The presence of putative colonies of L. cinctum was determined by microscopic observation at $\times 20$.

Orchard studies using under-the-canopy impact sprinklers. A second orchard (20 ha) located $5 \mathrm{~km}$ south of Yakima, WA, was used for these studies. The orchard was comprised of 12-year-old 'Redhaven' planted on a spacing of $4.3 \mathrm{~m}$ between trees and $4.9 \mathrm{~m}$ between rows and irrigated using under-the-canopy sprinklers (model L20H Rainbird). A mature tree with a large canker in the main scaffold/trunk area was used as an inoculum source in dispersal experiments. Petri dishes $150 \mathrm{~mm}$ in diameter containing $40 \mathrm{ml}$ of LSM were placed $0.5,0.9,1.4,1.8,2.3,2.7,3.2,3.6$, $4.1,4.5,5,5.4$, and $5.9 \mathrm{~m}$ from the canker and arranged 110 degrees azimuth diagonal to the canker. Two dishes were placed atop a 10 -cm-high cinder block at each location; the cover of one was removed during watering while the second remained covered to serve as a control. The angle of the water stream of an impact sprinkler 2.1 $\mathrm{m}$ from the canker was adjusted so that the water stream impacted directly on the canker. About $10 \mathrm{ml}$ of sterile distilled water was applied to the canker $1 \mathrm{~h}$ prior to the experiment. Water was applied at 2.46 $\mathrm{kg} / \mathrm{cm}^{2}$. The water stream was allowed to impact on the canker 10 times, after which dishes were covered. At the conclusion of the experiment, dishes were transported to the laboratory, incubated as described above, and the number of colonies of $L$. cinctum was determined. The experiment was repeated 12 days later.

Data analyses. Seasonal spore production. The relationship between monthly spore production, temperature, and precipitation was examined using the correlation analysis procedure of JMP Statistical Discovery Software (SAS Institute, Cary, NC). In order to stabilize variances, the $\operatorname{logarithm}_{\text {(base 10) }}$ of monthly conidia concentrations +1 were used in all correlation analyses. The significance of correlation coefficients was determined with a standard $t$ test at $P<0.05$. The relationships between spore production during irrigation sets and temperature were determined similarly.

Dispersal studies. Regression analysis was used to examine the relationship between the logarithm (base 10) of colony numbers $+1(Y)$ and horizontal distance $(D)$ from the canker, degrees azimuth $(A)$ to the canker, and distance $\times$ degrees azimuth $(A D)$.

\section{RESULTS}

Seasonal production of conidia. All sporulation values presented are the number of conidia per $\mathrm{mm}^{2}$ canker surface area $\times 10^{5}$. In general, sporulation was highest during the spring and summer months, but conidia were produced throughout the year. For example, in the peach orchard in
1994, sporulation ranged from a minimum of 0.41 in November to a maximum of 20.0 in May (Fig. 1). In 1995, values ranged from 1.2 in December to 26.4 in May. A similar pattern of spore production was observed on cherry (Fig. 2). Values ranged from 0.3 in February to 8.7 in June 2002. In 2003, values ranged from 0.5 in January to 9.0 in June. Numbers of conidia were positively correlated $(P<0.05)$ with temperature on cherry during both years of the study and on peach in 1994 and 1995, but not in 1993 (Table 1). Significant $(P<$ 0.05 ) correlations between sporulation and precipitation were not detected for either host.

Production of conidia during overthe-canopy irrigation. Conidia were detected in all 1994 and 1995 irrigation experiments (Fig. 3). In 1994, values ranged from 1.5 on 2 June to 29.0 on 23 June. During 1995, values ranged from 7.0 on 13 July to 34.0 on 5 June. The number of conidia produced per $\mathrm{mm}^{2}$ of canker surface area was not significantly $(P<0.05)$ correlated with temperature during the irrigation.

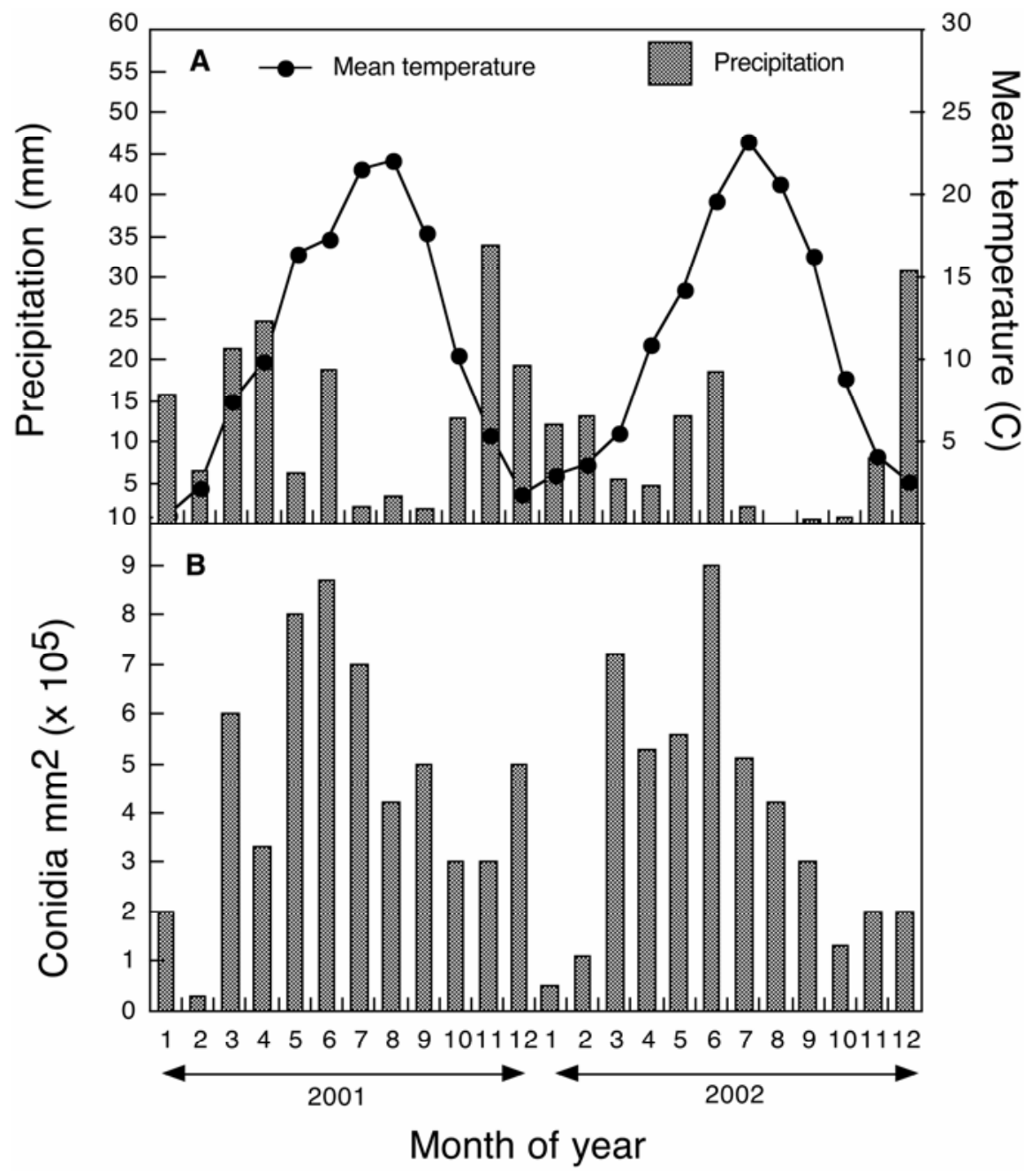

Fig. 2. Effect of time of year on sporulation of Leucostoma cinctum on cankers on 'Bing' cherry trees in Prosser, WA, during 2001 to 2002. Presented are A, average monthly temperature and total monthly precipitation and $\mathbf{B}$, number of conidia per $\mathrm{mm}^{2}$ of canker surface area collected from water-borne spore traps. Values represent the mean number of conidia per $\mathrm{mm}^{2}$ recovered from 20 cankers. 
Dispersal of $L$. cinctum conidia. Laboratory experiments. The impaction of water drops on canker surfaces dispersed conidia up to $100 \mathrm{~cm}$ from the canker (Fig. 4). Colony numbers were highest in dishes placed 20 and $40 \mathrm{~cm}$ from the canker. In general, the number of colonies decreased with increasing distance from the canker, e.g., at 180 degrees azimuth 95, 60, 1, 0, and 0 colonies were recorded in dishes 20 , $40,50,80$, and $100 \mathrm{~cm}$ from the canker in experiment 2, respectively. Colonies of $L$. cinctum were not present in any dishes left covered during the experiments.

An $F$ test (15) indicated that the regression results from experiments 1 and 2 were not significantly different. The data from the two experiments were combined, and the equation

$$
\log (Y+1)=5.6+-0.06 * D
$$

(where $Y=$ number of $L$. cinctum colonies per petri dish and $D=$ horizontal distance from canker) described the relationship between colony number and horizontal distance from the canker with a coefficient of determination $\left(R^{2}\right)$ of 0.81 at $P<0.01$. Degrees azimuth and interactions between distance and degrees azimuth were not significant $(P<0.05)$.

Orchard studies using over-the-canopy irrigation. The volume of water in each petri dish precluded determining the number of $L$. cinctum colonies. Seventy-six and 93\% of dishes contained Leucostoma colonies in the first and second experiments, respectively (data not shown). Colonies were detected at heights of up to 1.52 and $1.83 \mathrm{~m}$ in the first and second experiments, respectively. All dishes positioned in tree crotches contained $L$. cinctum. Colonies of $L$. cinctum did not develop in dishes left covered during irrigation.

Orchard studies using under-the-canopy irrigation. Colonies of $L$. cinctum were observed in petri dishes situated from 0.5 to $5.9 \mathrm{~m}$ from cankers during the application of water. There was no apparent pat-

Table 1. Coefficients of correlation $(r)$ between average monthly temperature, precipitation, and production of conidia by Leucostoma cinctum on peach and cherry cankers in the Yakima Valley during 1993 to 1995 and 2001 to 2002, respectively

\begin{tabular}{llcl}
\hline & & \multicolumn{2}{c}{$r^{\mathbf{a}, \mathbf{b}}$} \\
\cline { 3 - 4 } Host & Year & Temp. $^{\mathbf{b}}$ & Precip. $^{\mathbf{b}}$ \\
\hline Peach & $1993^{\mathrm{c}}$ & $-0.5346 \mathrm{NS}^{\mathrm{d}}$ & $-0.5585 \mathrm{NS}$ \\
& 1994 & $0.6582^{* \mathrm{c}}$ & $-0.1951 \mathrm{NS}$ \\
& 1995 & $0.6435^{*}$ & $-0.4111 \mathrm{NS}$ \\
Cherry & 2001 & $0.6375^{*}$ & $-0.1437 \mathrm{NS}$ \\
& 2002 & $0.5947^{*}$ & $-0.1709 \mathrm{NS}$ \\
\hline
\end{tabular}

a The significance of correlation coefficients was determined with a standard $t$ test at $P<0.05$.

${ }^{b}$ Analyses for temperature and precipitation were conducted on log transformed data.

${ }^{\mathrm{c}}$ Data collected from July to December.

${ }^{\mathrm{d}} \mathrm{NS}=$ not significant

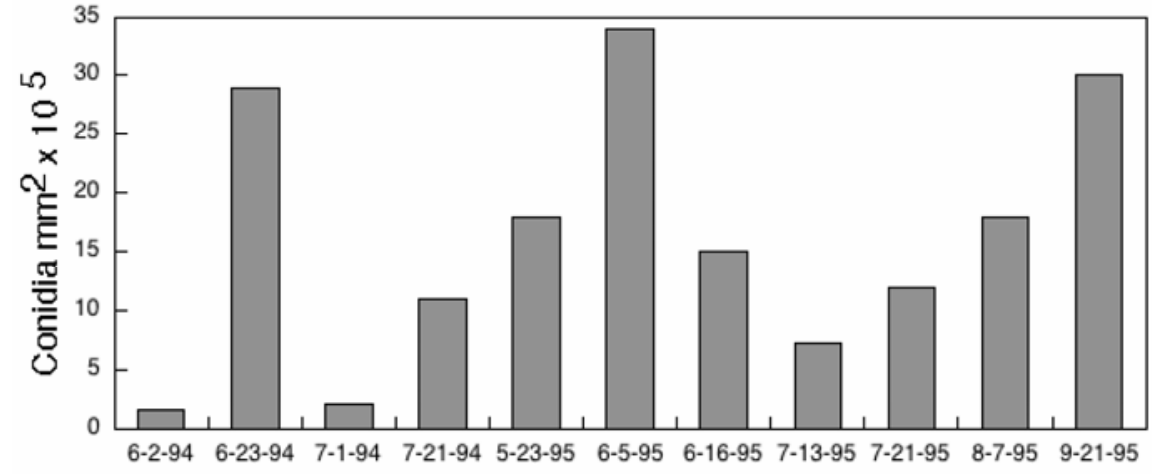

\section{Sampling date}

Fig. 3. Sporulation of Leucostoma cinctum on cankers on 'Redhaven' peaches during over-the-canopy irrigation in Wapato, WA, during 1994 to 1995 . Conidia were collected in water-borne spore traps positioned beneath cankers for $6 \mathrm{~h}$ during irrigation sets. Values represent the mean number of conidia per $\mathrm{mm}^{2}$ of canker surface area recovered from 20 cankers.

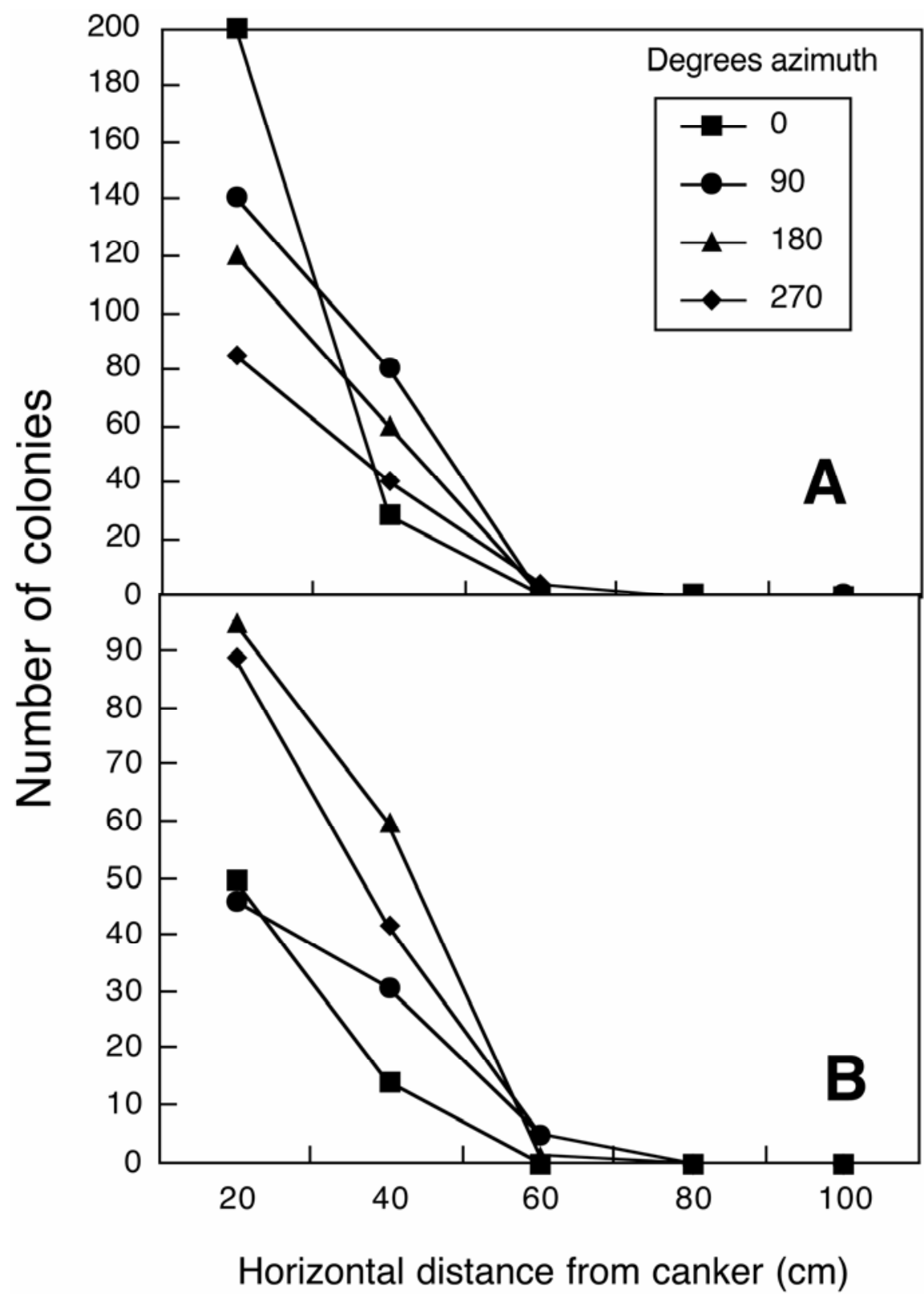

Fig. 4. Number of colonies of Leucostoma cinctum splash dispersed to petri dishes positioned at different horizontal distances from a canker. Water drops were released onto canker surfaces from a burette positioned $2 \mathrm{~m}$ above the canker. 
tern to dispersal using this irrigation method, and the number of colonies in dishes was not a function of distance from the inoculum source at the distances tested. Colonies of $L$. cinctum did not develop in dishes left covered during the application of water.

\section{DISCUSSION}

The results demonstrate that conidia of L. cinctum are produced in cherry and peach orchards in Eastern Washington throughout the year and the inoculum concentration is highest during spring and summer. The spring-summer sporulation peak documented in our studies is similar to patterns documented in other irrigated orchards $(2,11)$. Bertrand and English (2) demonstrated wind-blown rain was a primary means of dispersal for conidia in French Prune orchards. Our results show L. cinctum appears to be dispersed in stone fruit orchards by natural precipitation and irrigation. In addition, both over-thecanopy and under-tree sprinkler irrigation can promote sporulation and disperse conidia during the growing season in Eastern Washington. This may be particularly important in regions where measurable precipitation is very sporadic during the growing season. These findings offer growers in Eastern Washington a means to reduce disease losses by altering pruning and irrigation practices that contribute to the development of Leucostoma canker.

The recognition that irrigation practice can be an important factor in the dispersal of conidia of $L$. cinctum has implications for disease management in the region. Producers of stone fruit in Eastern Washington have considered $L$. cinctum to be a pathogen most active during the autumn and winter months (9), when most annual precipitation is received, and they have adjusted their dormant pruning practices to avoid tree wounding during these periods. Our results on peach and cherry suggest pruning periods may be coincident with the early periods of the sporulation peak, and therefore growers should consider pruning trees during mid- to late-winter when inoculum concentrations are lower. Inoculum production and dispersal by irrigation practices commonly used in Eastern Washington should be considered when developing a pruning plan. "Summer" pruning, which consists of the removal of excess vegetative growth during early summer, is a practice commonly used to promote the development of anthocyanins in fruit to enhance marketability $(12,13)$. The resulting wounds may become infected if irrigation water impacts cankers and splashes inoculum to wounds prior to healing. Delaying irrigation until wounds have healed could perhaps reduce infection of summer pruning in orchards with canker-infested trees. Complete healing of peach wounds requires 390 (base $=$ $0^{\circ} \mathrm{C}$ ) accumulated degree-days (3). Based on temperatures recorded in the Wapato, WA, orchard during 2000 to 2004 , healing would have required 14 to 21 days. Irrigation delays of this magnitude would be acceptable to Washington growers provided that compensatory water was applied during previous irrigation sets.

The sporulation and dispersal of L. cinctum during irrigation sets also raises interesting issues about the types of irrigation utilized in stone fruit orchards and their role in the prevalence and severity of the disease in the region. It is possible that the conversion to irrigation systems less likely to wet canker surfaces and distribute the causal organism to infection courts might over the long term reduce the incidence and severity of the disease. The two options available to growers appear to be to convert impact sprinkler systems to underground drip or microsprinkler irrigation. Both methods would be less likely to wet canker surfaces and provide the water drops necessary for dispersal. Alteration of irrigation types and/or practices has been recommended to reduce the incidence and severity of several orchard diseases $(6,7,14)$. Michailides and Morgan (14) recommended lowering sprinkler angles to facilitate the orchard management of panicle blight of pistachio. Grove and Boal (7) recommended shortening the duration of over-the-canopy irrigation sets to reduce the incidence of fruit rots of apple and pear caused by Phytophthora cactorum. However, neither of these recommendations involved the expenses incurred during conversion of an impact sprinkler irrigation system to drip or microsprinkler systems. Therefore, producers should carefully weigh the costs versus benefits of switching irrigation methods. The cost of a microsprinkler irrigation system in a new orchard is estimated at US\$5,375 per hectare (10). The costs could be higher in an established orchard. Therefore, the decision to convert irrigation systems depends in large part on the profitability of the crop. For example, gross returns from a mature sweet cherry orchard in Washington are about US\$33,700 per hectare (10). At loss levels due to Leucostoma canker of $5 \%$ per year, the costs required for the installation of an irrigation system less conducive to the spread of $L$. cinctum would be recouped in 3 to 4 years. At current prices, recovering irrigation conversion costs in peach and nectarine orchards would require 6 to 7 years (G. G. Grove, unpublished). Because of high irrigation conversion costs and economic losses related to Leucostoma canker, growers should therefore consider the effects of irrigation system on disease development when planning and designing new orchards.

\section{ACKNOWLEDGMENTS}

We appreciate the support of this research by the Washington State Tree Fruit Research Commission and the Washington State University Agricultural Research Center, Pullman.

\section{LITERATURE CITED}

1. Barakat, R. M., Johnson, D. A., and Grove, G. G. 1995. Factors affecting conidial exudation and survival, and ascospore germination of Leucostoma cincta. Plant Dis. 79:1245-1248.

2. Bertrand, P. F., and English, H. 1976. Release and dispersal of conidia and ascospores of Valsa leucostoma. Phytopathology 66:987-991.

3. Biggs, A. R. 1986. Prediction of lignin and suberin deposition in boundary zone tissue of wounded tree bark using accumulated degree days. J. Am. Soc. Hortic. Sci. 111:757-760.

4. Biggs, A. R. 1989. Integrated approach to controlling Leucostoma canker of peach in Ontario. Plant Dis. 73:869-874.

5. Biggs, A. R. 1995. Leucostoma canker. Pages 28-30 in: Compendium of Stone Fruit Diseases. J. M. Ogawa, E. I. Zehr, G. W. Bird, D. F. Ritchie, K. Uriu, and J. K. Uyemoto, eds. American Phytopathological Society, St. Paul, MN.

6. Grove, G. G. 2002. Influence of temperature and wetness duration on infection of cherry and peach foliage by Wilsonomyces carpophilus. Can. J. Plant Pathol. 24:40-45.

7. Grove, G. G., and Boal, R. J. 1991. Influence of temperature and wetness duration on infection of immature apple and pear fruit by Phytophthora cactorum. Phytopathology 81:14651471.

8. Grove, G. G., Dugan, F. M., and Boal, R. J. 1992. Perennial canker of apple: Seasonal host susceptibility, spore production, and perennation of Cryptosporiopsis perennans in eastern Washington. Plant Dis. 76:1109-1114.

9. Grove, G. G., Regner, K. M., and Johnson, D. A. 1987. Cytospora canker of stone fruits. Washington State University Coop. Ext. Bull. EB1448.

10. Hinman, H., and Watson, J. 2003. Cost of establishing and producing sweet cherries in Central Washington in 2003. Washington State University Coop. Ext. Bull. 1957E. Online publication.

11. Leupschen, N. S., and Rohrbach, K. G. 1969 Cytospora canker of peach trees: Spore availability and wound susceptibility. Plant Dis. Rep. 53:869-872.

12. Marini, R. P. 1985. Vegetative growth, yield, and fruit quality of peach as influenced by dormant pruning, summer pruning and summer topping. J. Am. Soc. Hortic. Sci. 110:133139.

13. Marini, R. P. 1986. Defoliation, flower bud cold hardiness, and bloom date of peach as influenced by pruning treatments. J. Am. Soc. Hortic. Sci. 111:391-394.

14. Michailides, T. J., and Morgan, D. P. 1993. Spore release by Botryosphaeria dothidea in pistachio orchards and disease control by altering the trajectory angle of sprinklers. Phytopathology 83:145-152.

15. Neter, J., and Wasserman, W. 1974. Applied Linear Statistical Models. 1st ed. Richard D. Irwin, Inc., Homewood, IL.

16. Regner, K. M., Johnson, D. A., and Gross, D. C. 1990. Etiology of canker and dieback of sweet cherry in Washington State. Plant Dis. 74:430-433.

17. Schulz, U., and Schmidle, A. 1983. Zur epidemiologie der Valsa Krankheit. Angew. Botanik 57:99-107. 